\title{
President's Report 2018
}

\section{Introduction and thanks}

The new members of the IMS Committee for 2018 are Leo Creedon and Martin Mathieu, replacing outgoing members Bernd Kreussler and Mícheál Mac an Airchinnigh, both of whom I would like to thank for their dedicated work on the Committee.

I wish to record the Society's thanks to Anthony O'Farrell for his ongoing excellent work as editor of the IMS Bulletin. Thanks also go to the other members of the Bulletin team: Ian Short (problem page maintainer), Gordon Lessells (who oversaw printing and distribution), and the Editorial Board (Tom Carroll, Jim Cruickshank, Dana Mackey, Pauline Mellon, Ann O'Shea, Ian Short, and Thomas Unger).

Finally, I would also like to thank Richard Timoney for maintaining the Society's webpages.

\section{IMS meetings and IMS-supported meetings}

The Society's 2018 "September meeting" was held at University College Dublin (30-31 August). As usual, this functioned as both the main scientific meeting of the Society and its AGM. At the AGM, Pauline Mellon was elected as the incoming president, and Tom Carroll as the incoming vice-president, of the IMS. I wish them well when their terms start on 1 January 2019. Special thanks go to the organisers, Pauline Mellon, Chris Boyd, and Michael Mackey, for organising this event. The 2019 "September meeting" will be held in NUIG.

The Committee also met on 14 December in University College Cork. That meeting was followed immediately by the 2nd IMS Invited Lecture Burnside Algebras of Finite Groups, given by Götz Pfeiffer. It is my hope that this new tradition of annual invited lectures following the end-of-year Committee meetings will continue.

At the December Committee meeting, the recent survey of members was discussed. Supported by the opinions in that survey, a decision was made to increase membership rates by a modest amount. It was also decided that the IMS Bulletin should move to an electronic format in future.

The Society supported the following meetings held during 2018: 
- Quantum Information Theory, UCC: February 15.

- Groups in Galway, NUIG: May 18-19.

- British and Irish Geometry Meeting 2018, QUB: June 1-2.

- International Conference on Complex Analysis, Potential Theory and Applications, UCD: June 11-15.

- Topics in Functional Analysis, NUIG: July 9-11.

- Women in Mathematics in Ireland, UCD: August 29.

Thanks go to the Treasurer, Götz Pfeiffer, for efficiently overseeing the application process, and for making the task of deciding on funding less onerous.

\section{EMS Meetings}

The annual European Mathematical Society Meeting of Presidents took place at Maynooth University on 14-15 April. The meeting included three event presentations (including one on the $2020 \mathrm{Eu}-$ ropean Congress of Mathematicians in Slovenia) and seven national society presentations (including one by the IMS). It was a useful opportunity to discuss matters of mutual interest with other national mathematical society presidents and representatives. Various documents, including a report on the meeting, can be found at http: //archive.maths.nuim.ie/staff/sbuckley/meetings/18EMS/

I also attended the EMS Council Meeting (Prague, 23-24 June) as the IMS delegate. A new president (Volker Mehrmann) and other officers were elected, and various items of EMS business were discussed.

\section{Education Subcommittee}

The Education Subcommittee discussed textbooks during 2018. Concern was raised about content errors in books, as well as misalignments between books and the syllabus. A system for vetting textbooks could be useful, and this matter will be discussed further.

The Subcommittee advised me with regard to the Teaching Council Subject Criteria Consultation Session which was to place in Maynooth on 14 November, and I subsequently reported to the IMS Committee. We chose Ronan Flatley to represent us at that session. Ronan kindly agreed to attend, and produced a report on the session. The Teaching Council had a mid-December deadline for feedback. On the basis of discussions within both the IMS Committee and the Education Subcommittee, I subsequently sent a letter to the Teaching Council indicating some concerns that we had. 
I would like to thank the Subcommittee for its hard work throughout the year.

Stephen Buckley

E-mail address: sbuckley@nuim.ie

December 2018 